\title{
Vertical distribution and population structure of Macrosetella gracilis (Copepoda: Harpacticoida) in the Red Sea in relation to the occurrence of Oscillatoria (Trichodesmium) spp. (Cyanobacteria)
}

\author{
Ruth Böttger-Schnack, Dietrich Schnack
}

Institut für Meereskunde an der Universität Kiel, Düsternbrooker Weg 20, D-2300 Kiel, Federal Republic of Germany

\begin{abstract}
Macrosetella gracilis is closely associated with the epipelagic filamentous cyanobacteria Oscillatoria (Trichodesmium) spp., which serve as food for adults and as a substrate for the non-pelagic juveniles. Plankton sampling in the Red Sea in 1980-81, using a multiple opening-closing net with 0.1 $\mathrm{mm}$ mesh, revealed $M$. gracilis populations from the surface to the deepest stratum sampled $(1650 \mathrm{~m})$. Their population biology was investigated in the central and northern Red Sea, and included analysis of ontogenetic composition and size distribution, sex ratio and percentage of egg-bearing females. By relating population structure differences to variations in the abundance of Trichodesmium spp. at the surface, a hypothetical life cycle for the copepod could be proposed: (1) Reproduction takes place only in surface waters during blooms of Trichodesmium spp. (2) Short-term, diurnal vertical migrations are not apparent. (3) At the surface and in the lower meso- and bathypelagic zone, the female population consists mainly of small specimens; in the upper part of the oxygen minimum zone, at 300 to $450 \mathrm{~m}$, long-lived large, non-reproductive females are congregated. The significance of these midwater populations in the life cycle of $M$. gracilis is discussed under 2 alternative assumptions: (a) the copepods survive periods of Trichodesmium spp. scarcity in a resting phase, or (b) the part of the population in deep waters is moribund. The unusually deep occurrence of $M$. gracilis may have some significance for the nutrient cycle in these waters.
\end{abstract}

\section{INTRODUCTION}

Massive blooms of the marine filamentous cyanobacteria Oscillatoria (Trichodesmium) spp. are a characteristic feature in Red Sea surface waters (Carpenter 1983). For tropical marine plankton communities, the Trichodesmium blooms have a 2 -fold significance. (1) The cyanobacteria use molecular nitrogen as an additional nitrogen source (Goering et al. 1966) and thereby become an important primary producer in oligotrophic marine areas, as in the Red Sea. Naqvi et al. (1986) estimated that nitrogen fixation by Trichodesmium may contribute $6 \%$ to total primary production in this area. (2) The dense mats of Trichodesmium filaments that drift on the sea surface serve as a substrate for a specific association of organisms. Members of this community include bacteria and phytoplankters, such as the dinoflagellate Peridinium trochoideum and diatoms of the genus Nitzschia, as well as the hydroid Pelagiana trichodesmiae (Borstad \& Borstad 1977). The harpac- ticoid copepod Macrosetella gracilis Dana, 1848 is the largest and phylogenetically most advanced member of this microcommunity yet discovered. Trichodesmium filaments serve as food for the adults (Roman 1978) and as a substrate for the non-pelagic juveniles, which grasp the filaments by their hook-like appendages (Björnberg 1965).

The relative abundance of Macrosetella gracilis within the total copepod community of tropical seas is poorly known. Michel \& Foyo (1977) reported it as one of the 10 most common copepod species in the Caribbean Sea, where Trichodesmium blooms can be observed regularly (Borstad \& Borstad 1977. Corredor 1977. Carpenter 1983). It accounted for about $1 \%$ of the total number of copepods, excluding nauplii, sampled with $0.1 \mathrm{~mm}$ mesh nets in the upper $2000 \mathrm{~m}$. This is somewhat lower than the corresponding value $(3 \%)$ in the upper $1650 \mathrm{~m}$ in the Red Sea found by Böttger (1987).

The nauplii of Macrosetella gracilis have been sam- 
pled in plankton nets only in cases when Trichodesmium blooms were occurring (Krishnaswamy 1951, Tokioka \& Bieri 1966). The vertical range of the habitat of these juveniles is determined by the vertical extension of the bloom. This can be quite variable, ranging from a few centimetres (Devassy et al. 1978) to several metres (Belogorskaya 1970, Bryceson 1980), but is generally restricted to surface waters.

The occurrence of later copepodids and adults is not restricted to the surface. They have been found in the Atlantic Ocean to a depth of $1750 \mathrm{~m}$ (Grice 1963, Owre \& Foyo 1964) and Weikert (1982) has also reported its occurrence in deep waters of the Red Sea. It is still unknown whether a relationship exists between surface populations and deep water specimens of $\mathrm{MaC}$ rosetella gracilis and if so what the nature of relationship may be. Existing information on the vertical distribution and migration is rather scarce (Moore \& Foyo 1963, Roehr \& Moore 1965) and insufficient to prove any hypothesis on this question. There is no information at all available on possible seasonal or productionrelated differences in the depth distribution of $M$. gracilis populations. The ontogenetic composition and sex ratio of surface and deep water populations are also unknown.

This lack of information may be mainly due to the facts that mesh sizes of about $0.3 \mathrm{~mm}$, as frequently used in marine zooplankton investigations (Roehr \& Moore 1965), are not adequate for quantitatively sampling this very slender copepod species (Böttger 1985), and that finer mesh net sampling in pelagic regions has generally been restricted to the upper $200 \mathrm{~m}$.

The present paper is based on samples taken with $0.1 \mathrm{~mm}$ mesh nets. It considers the population structure and vertical distribution of Macrosetella gracilis in the upper $450 \mathrm{~m}$ of the central and northern parts of the Red Sea during autumn and winter. Some preliminary information is also included on the deeper layers, down to $1650 \mathrm{~m}$. All developmental stages of the copepod have been included in the analysis, although the smallest nauplii may not have been sampled quantitatively. Several population parameters, such as ontogenetic composition, sex ratio, size and percentage of eggbearing females are used to characterize different $M$. gracilis populations in the region studied. By correlating the findings with regional and seasonal variations in the abundance of Oscillatoria (Trichodesmium) spp., a general outline of this copepod's life cycle is proposed.

\section{MATERIAL AND METHODS}

Zooplankton samples were collected from the RV 'Valdivia' in the northern Red Sea, above the Kebrit
Deep, between 9 and 15 October 1980; and in the central Red Sea, above the Atlantis II Deep, between 15 October and 8 November 1980, and between 21 and 24 February 1981. The geographical locations are shown in Fig. 1. A single reference station, situated north of the Kebrit Deep, was sampled on 9 October 1980

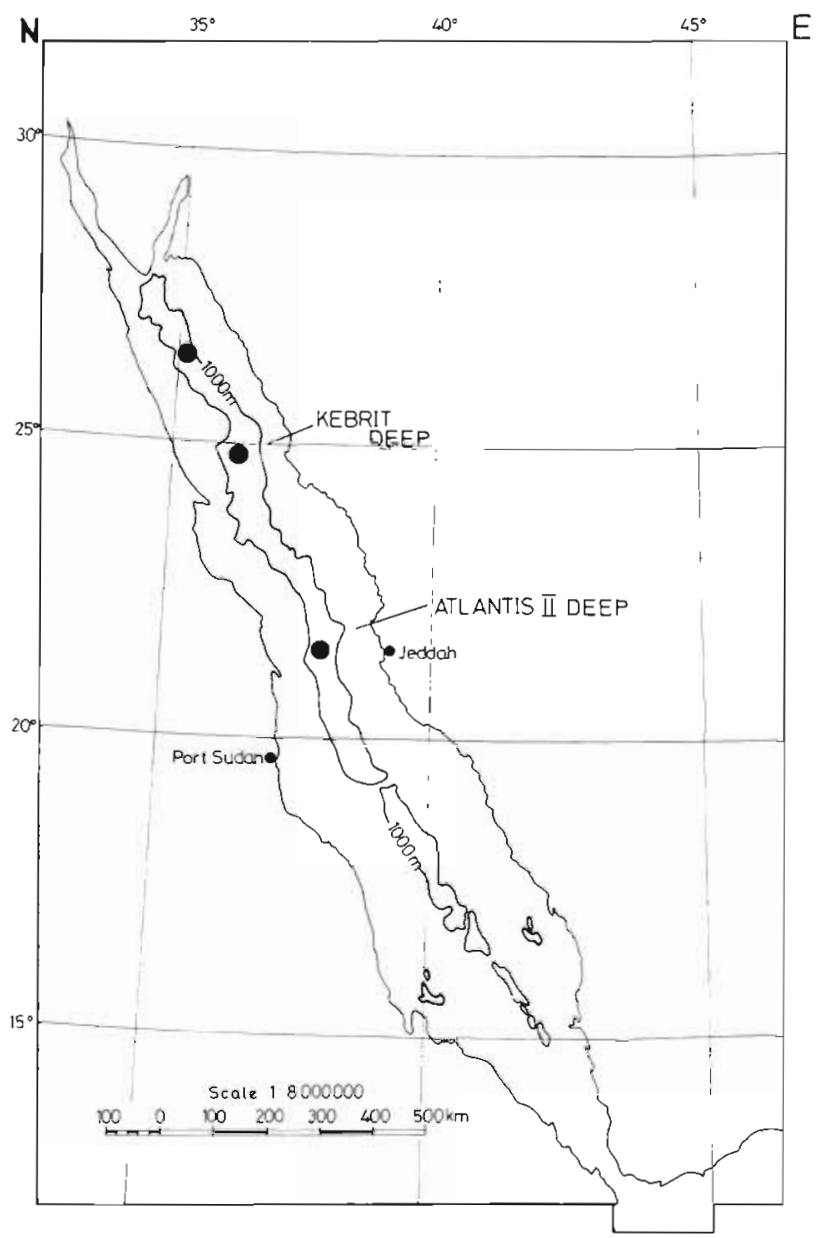

Fig. 1. Plankton sampling stations in the Red Sea during Meseda 3, 1980-81

The sampling was part of a multi-disciplinary environmental research program, Meseda 3 (Thiel et al. 1986). A multiple opening-closing net with a mouth area of $0.25 \mathrm{~m}^{2}$ (Weikert \& John 1981) equipped with 5 nets of $0.1 \mathrm{~mm}$ mesh was towed vertically at a speed of $0.5 \mathrm{~m} \mathrm{~s}^{-1}$. The depth of the net was determined by the length of the towing wire during the sampling in October and November and by a depth-pressure recorder in February. As the wire angle was less than $10^{\circ}$, the actual depth limits of the vertical strata sampled varied less than $\pm 3 \mathrm{~m}$ from the preset values.

The routine program sampled the upper $450 \mathrm{~m}$ of the water column at $50 \mathrm{~m}$ intervals. A total of 27 vertical series were evaluated, 10 series each from the Atlantis 
II Deep and the Kebrit Deep, and 1 series from the northern reference station during autumn, plus 6 vertical series from the Atlantis II Deep during winter. Equivalent numbers of day and night samples were taken at each of the permanent stations. Samples at the northern reference station were collected during the night. Daytime samples were collected between 03:00 and 17:00 h (local time) in the Kebrit Deep area and between 11:00 and 15:00 $\mathrm{h}$ in the area of the Atlantis II Deep. The night-time samples were taken between 03:00 and 05:00 h and between midnight and 04:00 h. In autumn 1980 additional samples were taken in the Atlantis II Deep area from the upper $100 \mathrm{~m}$ at smaller, $20 \mathrm{~m}$ intervals, and from the deeper water layers down to $1650 \mathrm{~m}$ at larger intervals. In the upper $100 \mathrm{~m}, 3$ vertical series were taken during the day and 2 at night. Between 450 and $1050 \mathrm{~m}, 2$ series of samples were taken at $150 \mathrm{~m}$ intervals, one during the day and one at night. Between 1050 and $1650 \mathrm{~m} 1$ night-time series at $200 \mathrm{~m}$ intervals was collected. Depending on the strata sampled and assuming a filtration efficiency of $100 \%$, the volumes filtered ranged from $5 \mathrm{~m}^{3}(20 \mathrm{~m}$ intervals) to $50 \mathrm{~m}^{3}$ (200 $\mathrm{m}$ intervals).

Samples were fixed in a $4 \%$ formaldehyde-seawater solution buffered with hexamethylene tetramine. For sorting and storage, they were tranferred into a preservative of $5 \%$ propylene glycol, $0.5 \%$ propylene phenoxetol, and $94.5 \%$ filtered seawater (Steedman 1976). Copepods were counted under a stereomicroscope. In most cases, the entire sample was counted. Females, males, copepodids and nauplii were counted separately. The numnber of egg-bearing females was noted in each sample, but only data from the night-time series will be considered here. The daytime samples had been fractionated through larger-sized mesh gauze earlier, so that some of the females lost their egg sacs, which could not be identified in the samples. Empty exoskeletons and copepods showing an advanced degree of internal disintegration (carcasses) were counted separately and are not included in the abundance data.

Due to fixation, most of the copepods were slightly bent, so the size measurements include some uncertainties. In the present study, only females were considered for sizing and were grouped into 2 classes: $<1.2 \mathrm{~mm}$ and $>1.2 \mathrm{~mm}$ (anterior tip of prosome to end of caudal rami). A more precise analysis of the size frequency distribution was made on a limited number of individuals (Böttger-Schnack 1989 [companion article]). Females contained various numbers of small 'oil droplets', which possibly serve as a means of fat storage. From each region and season, 50 to 100 females were selected from samples of the epipelagic and mesopelagic zone to determine the degree of fullness with oil droplets.
The occurrence of Trichodesmium filaments was semiquantitatively estimated in all $0.1 \mathrm{~mm}$ mesh net samples and was categorized as 'none', 'very few', 'few' or 'many'. A more precise abundance estimate was made for samples of the uppermost 0 to $50 \mathrm{~m}$ or 0 to $20 \mathrm{~m}$ depth range at the Atlantis II Deep during autumn 1980. Samples taken in February, and those taken in the northern Red Sea, contained only very few filaments. In each of these 2 cases quantitative evaluation of filaments was restricted to 1 arbitrarily selected surface sample for comparison. The numbers of filaments were estimated from small subsamples, between $1 / 200$ and $1 / 6000$ of the entire net sample. The subsamples were filtered through membrane filters with $0.45 \mu \mathrm{m}$ pores, stained with a $4 \%$ eosine and $1.4 \%$ aniline solution, and counted under a microscope at $100 \times$ magnification. The number of filaments actually counted ranged from 20 to 500 per subsample.

For the entire water column, temperature profiles were obtained using a multisonde. Salinity and dissolved oxygen were determined from water samples during October and November 1980, but in February, a multisonde was used. The profiles were plotted using the mean values of usually 2 or 3 data sets at each of the permanent stations. In the Kebrit Deep, the temperature profile was derived from a single vertical series. At the northern reference station, no environmental data were obtained.

\section{RESULTS}

\section{Environmental data}

At all 3 stations 2 water masses, characteristic for the Red Sea, were evident: a warm surface layer with reduced salinity extending to a depth of 100 to $150 \mathrm{~m}$ and a deeper water mass with constant temperature and salinity down to about $2000 \mathrm{~m}$ (Fig. 2). In October and November 1980, sharp temperature gradients between 50 and $100 \mathrm{~m}$ separated the isothermal and isohaline deep water mass $\left(21.7^{\circ} \mathrm{C}\right.$ and $\left.40.5 \times 10^{-3} \mathrm{~S}\right)$ from a thin zone of surface water at temperatures of 28 to $30^{\circ} \mathrm{C}$ and salinities of $39.5 \times 10^{-3} \mathrm{~S}$ in the central Red Sea and $39.7 \times 10^{-3} \mathrm{~S}$ in the north. In February 1981 , surface temperatures in the central Red Sea had cooled to $24^{\circ} \mathrm{C}$. The temperature in the upper $100 \mathrm{~m}$ remained almost constant, but beneath this depth, it gradually decreased. The salinity profiles showed a marked gradient between 80 and $130 \mathrm{~m}$. This was more pronounced than during autumn (Fig. 2). Oxygen concentrations in the surface zone were high (4 to $5 \mathrm{ml} \mathrm{O}_{2} \mathrm{l}^{-1}$ ), but decreased sharply below $100 \mathrm{~m}$. Minimum values of $<1.3 \mathrm{ml} \mathrm{O}_{2} \mathrm{l}^{-1}$ were found in the central Red Sea between 300 and $600 \mathrm{~m}$ (Fig. 2). In the northern Red Sea (Kebrit Deep), the oxygen minimum zone was 
A

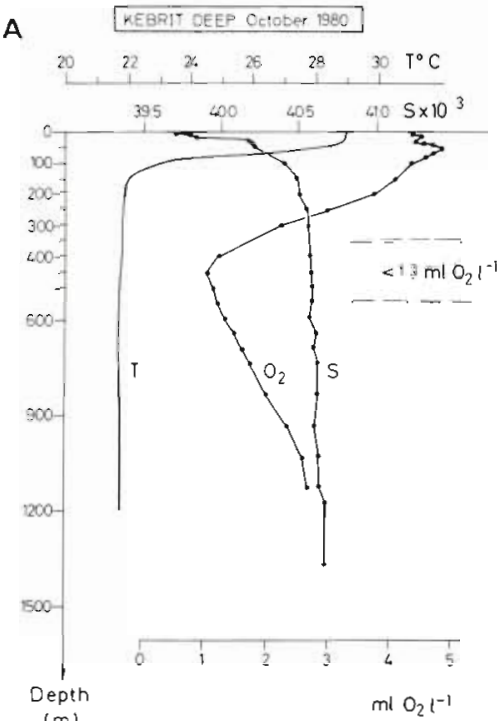

m)
B

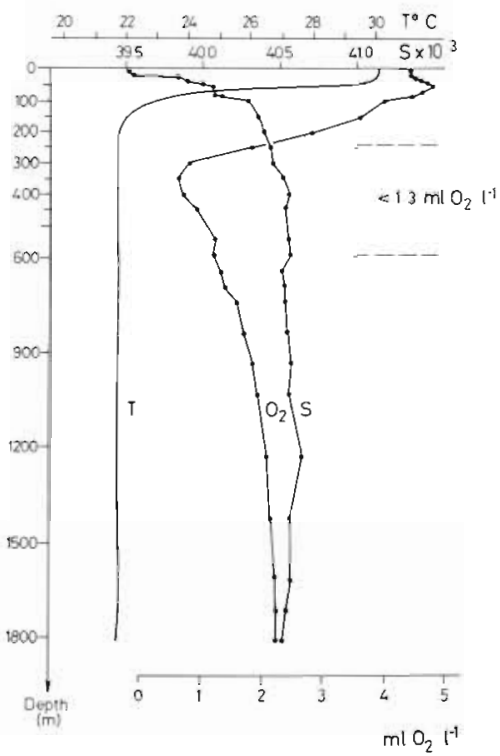

C

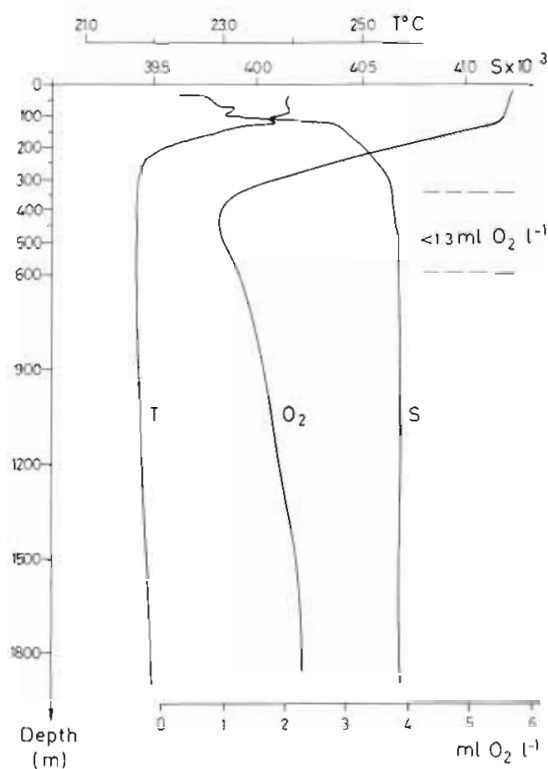

Fig. 2. Vertical profiles of temperature (T), salinity (S), and dissolved oxygen $\left(\mathrm{O}_{2}\right)$ in the northern (Kebrit Deep) and central Red Sea (Atlantis II Deep). (Modified from Lange et al. 1981)

situated deeper, and the minimum oxygen concentrations were somewhat higher than in the central part, as commonly found in the Red Sea (Morcos 1970).

\section{Trichodesmium spp.}

Filaments of Trichodesmium were encountered in the upper 50 or $20 \mathrm{~m}$ depth zone at all 4 sampling stations, but mostly at low abundance values, in the range of $10^{4}$ to $10^{5}$ filaments $\mathrm{m}^{-2}$. A bloom of Trichodesmium occurred in the Atlantis II Deep area in autumn 1980. Abundance values varied considerably during the 3 wk sampling period, from about $10^{4}$ to $10^{8}$ filaments $\mathrm{m}^{-2}$ (Fig. 3).

Highest numbers of Trichodesmium were always present in the uppermost net samples. During bloom conditions, single filaments were found down to $450 \mathrm{~m}$. Contamination of the closed nets during hauling through the dense surface patches cannot be ruled out, though this should not have been very significant. In the Kebrit Deep area, solitary filament bundles were present in the net samples to a depth of $150 \mathrm{~m}$.

\section{Macrosetella gracilis}

Populations of Macrosetella gracilis were present in the sampled depth range at all stations considered during this study. Total abundance, vertical distribution and population structure, however, varied considerably among stations and sampling dates. Highest concentrations were found in the central Red Sea (Atlantis II Deep) in autumn 1980, during Trichodesmium bloom conditions. Only on this occasion were juveniles (nauplii and copepodid stages I to V) encountered. Results are thus presented for this period first and taken as a basis to feature the specific differences at the remaining surveys.

\section{Central Red Sea, October and November 1980}

Both juvenile and adult stages were mainly concentrated in the uppermost 50 or $20 \mathrm{~m}$ depth interval sampled (Table 1). Beneath this surface zone, juveniles were found irregularly and in low numbers only. Adults were less confined to the surface waters. On the average only two-thirds of the males and one half of the females inhabiting the upper $450 \mathrm{~m}$ of the water column were caught in the 0 to $50 \mathrm{~m}$ interval (Table $1 \mathrm{a}$ ). But within the upper $100 \mathrm{~m}$ zone (Table 1b), where samples were taken at close intervals, about $80 \%$ of the adults and almost $100 \%$ of the juveniles were caught in the 0 to $20 \mathrm{~m}$ surface layer. Thus, numbers per $\mathrm{m}^{2}$ obtained from 50 or $20 \mathrm{~m}$ surface samples appeared to be roughly comparable and were combined for the following analysis.

Within the surface zone ( 0 to $50 \mathrm{~m}$ and 0 to $20 \mathrm{~m}$ ), the abundance of Macrosetella gracilis stages showed a substantial variation. Total ranges of values are given in Table 1. The time sequence of the data, as presented in Fig. 3, did not indicate any systematic day-night 

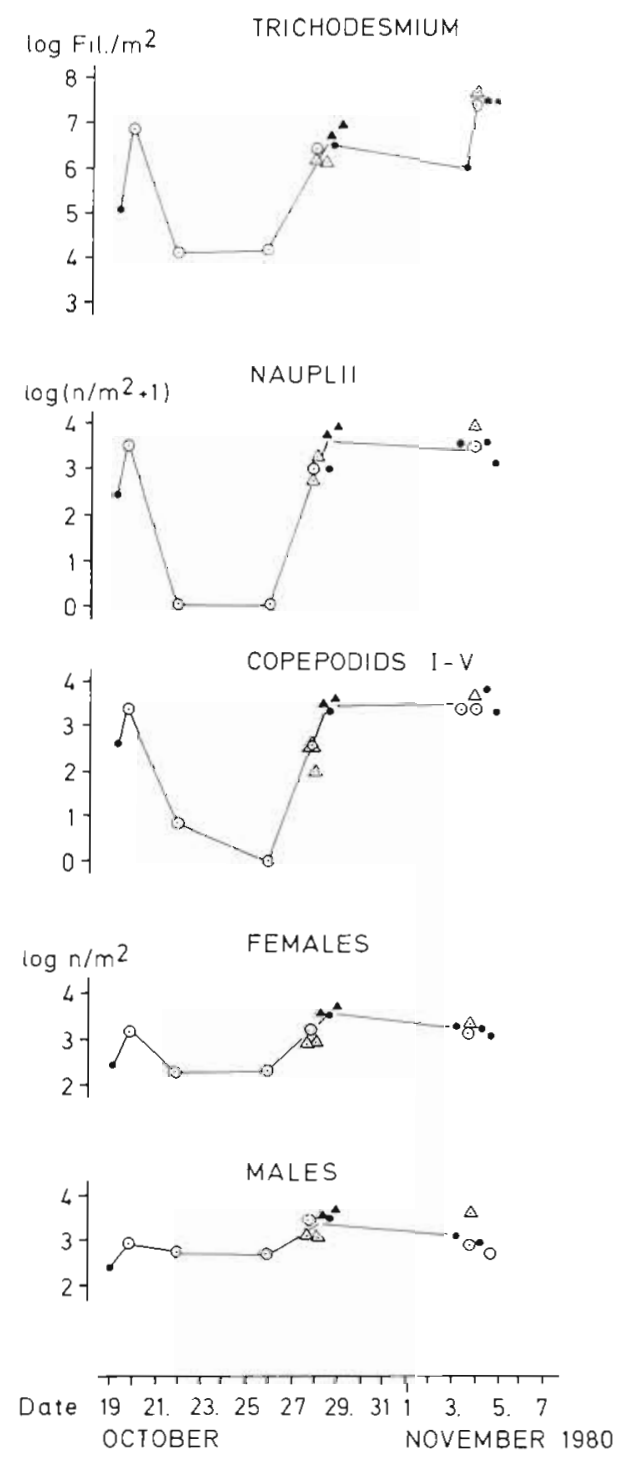

Fig. 3. Temporal variation in the abundance of Trichodesmium spp. filaments and Macrosetella gracilis juveniles and adults beneath $1 \mathrm{~m}^{2}$ in the upper $50 \mathrm{~m}(\bullet, 0)$ or $20 \mathrm{~m}(\Delta, \Delta)$ in the Atlantis II Deep during October and November 1980. Solid symbols: night; open symbols: day. Note logarithmic scale differences. Rather, the dominating feature was exceptionally low abundance values on 2 out of 15 sampling dates. The differences were most pronounced for juvenile stages. These were caught as single specimens only on these 2 dates, whereas adults were present in numbers of about $700 \mathrm{~m}^{-2}$ at the same time. On all other dates, juveniles outnumbered adults on average by a factor of about 4 .

The variation in the abundance of Macrosetella gracilis at the surface appeared to be closely related to changes in the abundance of Trichodesmium filaments, which were exceptionally rare on the same 2 sampling dates (Fig. 3). Spearman rank correlation coefficients (r) poved to be highly significant $(p<0.01)$ for both juvenile groups - nauplii $(r=0.70)$ and copepodids I to $V(r=0.78)-$ and for females $(r=0.61)$. For males, the variation was less pronounced and the correlation with Trichodesmium abundance was statistically significant at the $5 \%$ level only $(r=0.48)$.

In the 50 to $450 \mathrm{~m}$ depth range, compared to the surface layer, the variation of abundance values was generally less pronounced among sampling dates (see ranges in Table 1). The occurrence of juveniles was strongly related to the surface conditions - the abundance sequences in both depth ranges closely parallel each other (Fig. 4). For adults, on the other hand, there was no indication for any correlation with the surface population or with Trichodesmium conditions. A complete picture of the variation in the vertical distribution pattern is given in Fig. 5 for males and 2 size groups of females. The concentration of males decreased more or less continuously with depth and towards the end of the sampling period, whereas for females in total, some irregular layering was indicated beneath the surface zone, without any general trend over time. Large femains (>1.2 mm), however, showed a conspicuous and consistent pattern, with minimum concentrations between 50 and $250 \mathrm{~m}$ and a secondary maximum in the range 250 to $450 \mathrm{~m}$ (Fig. 5).

Table 1. Macrosetella gracilis. Abundance of juveniles and adult beneath $1 \mathrm{~m}^{2}$ (a) in the upper $450 \mathrm{~m}$ (a) and (b) in the upper $100 \mathrm{~m}$ above the Atlantis II Deep during October and November 1980. $\bar{x}$ : arithmetic mean; R: range; n: number of sampling series

\begin{tabular}{|c|c|c|c|c|c|c|c|}
\hline \multirow[t]{3}{*}{ Depth (m) } & \multirow[b]{3}{*}{$n$} & \multirow{2}{*}{\multicolumn{2}{|c|}{$\begin{array}{c}\text { Juveniles } \\
\text { (Nauplii + copepodids) }\end{array}$}} & \multicolumn{4}{|c|}{ Adults } \\
\hline & & & & & & & \\
\hline & & $\overline{\mathrm{x}}$ & $\mathrm{R}$ & $\overline{\mathrm{x}}$ & $\mathrm{R}$ & $\overline{\mathrm{x}}$ & $\mathrm{R}$ \\
\hline \multicolumn{8}{|c|}{ (a) Upper $450 \mathrm{~m}$} \\
\hline $0-50$ & 10 & 4200 & $(0-11000)$ & 1400 & $(190-3800)$ & 1300 & $(280-3700)$ \\
\hline $50-450$ & 10 & 235 & $(0-520)$ & 1400 & $(1200-2100)$ & 740 & $(260-1500)$ \\
\hline $0-450$ & 10 & 4400 & $(0-11000)$ & 2800 & $(1400-5000)$ & 2000 & $(980-4400)$ \\
\hline \multicolumn{8}{|c|}{ (b) Upper $100 \mathrm{~m}$} \\
\hline $0-20$ & 5 & 7300 & $(860-13000)$ & 2850 & $(800-5000)$ & 3300 & $(1000-7200)$ \\
\hline $20-100$ & 5 & 180 & $(4-270)$ & 670 & $(500-970)$ & 600 & $(380-950)$ \\
\hline $0-100$ & 5 & 7400 & $(960-13000)$ & 3500 & $(1600-5600)$ & 3900 & $(1800-7900)$ \\
\hline
\end{tabular}




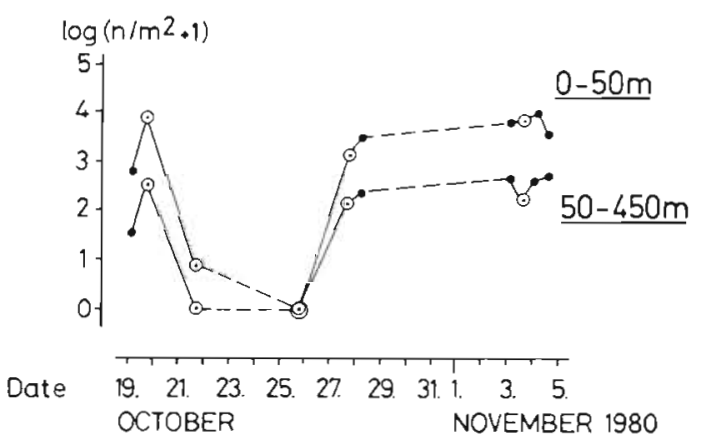

Fig. 4. Macrosetella gracilis. Number of nauplii and copepodids $I$ to $V$ beneath $1 \mathrm{~m}^{2}$ in the upper $50 \mathrm{~m}$ and 50 to $450 \mathrm{~m}$ in the Atlantis Il Deep during October and November 1980. Solid symbols: night; open symbols: day. Note logarithmic scale

Among females, small specimens were generally dominant. On average, individuals $<1.2 \mathrm{~mm}$ accounted for $75 \%$ of all females in the upper $450 \mathrm{~m}$. This proportion varied among profiles over the wide range of 50 to $90 \%$. Within the surface layer, the proportion of small females was regularly above $70 \%$, (with one exception only), and within the depth of the secondary maximum of large females it was in the range 50 to $70 \%$.

Size differences were also apparent in the percentage of females bearing eggs. In the surface zone $34 \%$ of small females carried egg sacs, as compared to only $19 \%$ of large females, giving an average of $31 \%$ for all females. In the vertical profile low numbers of egg- bearing females were also found regularly down to 150 $m$, and single specimens were collected as deep as 450 $m$. The sex ratio was, on average, well balanced at the surface, but varied between $2: 1$ and $0.3: 1$ females to males at high and low Trichodesmium concentrations, respectively

The restricted number of sampling profiles going down to $1650 \mathrm{~m}$ revealed that Macrosetella gracilis populations beneath $450 \mathrm{~m}$ consisted mainly of females (Table 2a). Males and juveniles combined accounted for only $5 \%$ of all individuals sampled in this extended depth range. Juveniles were caught irregularly and may have entered the samples as contaminants from the surface waters. Males were regularly present but decreased in abundance toward greater depths. The female population was not reproductive at these depths. Only one egg-bearing specimen was found, which may also have been introduced as a contaminant. The proportion of large females $(>1.2 \mathrm{~mm})$ decreased with increasing depth. Between 1050 and $1650 \mathrm{~m}$, nearly all individuals were smaller than 1.2 $\mathrm{mm}$ (Table 2b).

\section{Central Red Sea, February 1981}

In winter 1981, the population of Macrosetella gracilis in the central Red Sea consisted exlusively of adults. One single nauplius was caught at 400 to $450 \mathrm{~m}$. Females were predominant, accounting for $90 \%$ of the total number of copepods in the upper $450 \mathrm{~m}$ (Table

Table 2. Macrosetella gracilis. Population structure in various habitat zones within the upper $1650 \mathrm{~m}$ of the water column above the Atlantis II Deep during autumn 1980

(a) Standing stock of juveniles and adults: mean numbers $\left(\mathrm{N} \mathrm{m}^{-2}\right)$ beneath $1 \mathrm{~m}^{2}$ and percentages (\%) in given layers. $n$ : number of sampling series

\begin{tabular}{|c|c|c|c|c|c|c|c|c|c|}
\hline \multirow{2}{*}{ Depth (m) } & \multirow[b]{2}{*}{$n$} & \multicolumn{2}{|c|}{ Females } & \multicolumn{2}{|c|}{ Males } & \multicolumn{2}{|c|}{ Juveniles } & \multirow{2}{*}{$\begin{array}{c}\text { Ratio } \\
\text { adults:juv. }\end{array}$} & \multirow{2}{*}{$\begin{array}{c}\text { Ratio } \\
\text { females:males }\end{array}$} \\
\hline & & $\mathrm{Nm}^{-2}$ & $\%$ & $\mathrm{Nm}^{-2}$ & $\%$ & $\mathrm{~N} \mathrm{~m}^{-2}$ & $\%$ & & \\
\hline $0-50$ & 10 & 1400 & (35) & 1300 & (62) & 4200 & (93) & 0.6 .1 & $1: 1$ \\
\hline $50-450$ & 10 & 1400 & (35) & 740 & (35) & 240 & (5) & 10.1 & $2: 1$ \\
\hline $450-1050$ & 2 & 710 & (17) & 60 & (3) & 72 & (2) & 11.1 & $12: 1$ \\
\hline $1050-1650$ & 1 & 510 & (13) & 4 & $(<2)$ & & & - & $130: 1$ \\
\hline $0-1650$ & & 4000 & $(100)$ & 2100 & $(100)$ & 4500 & $(100)$ & $1.4: 1$ & 21 \\
\hline
\end{tabular}

(b) Standing stock of small $(<1.2 \mathrm{~mm})$ and large $(>1.2 \mathrm{~mm})$ females. For abbreviations, see Table $2 a$

\begin{tabular}{|c|c|c|c|c|c|c|}
\hline \multirow[t]{2}{*}{ Depth $(m)$} & \multirow[b]{2}{*}{$n$} & \multicolumn{2}{|c|}{$<1.2 \mathrm{~mm}$} & \multicolumn{2}{|c|}{$>1.2 \mathrm{~m}$} & \multirow{2}{*}{$\begin{array}{c}\text { Ratio } \\
<1.2:>1.2 \mathrm{~mm}\end{array}$} \\
\hline & & $\mathrm{N} \mathrm{m}^{-2}$ & $\%$ & $\mathrm{Nm}^{-2}$ & $\%$ & \\
\hline $0-50$ & 10 & 1100 & (34) & 270 & $(34)$ & $4: 1$ \\
\hline $50-450$ & 10 & 1000 & (31) & 4.30 & $(56)$ & $2: 1$ \\
\hline $450-1050$ & 2 & 640 & $(20)$ & 72 & (9) & $13: 1$ \\
\hline $1050-1650$ & 1 & 500 & (15) & 4 & $(<1)$ & $130: 1$ \\
\hline $0-1650$ & & 3300 & $(100)$ & 780 & $(100)$ & $4 \cdot 1$ \\
\hline
\end{tabular}



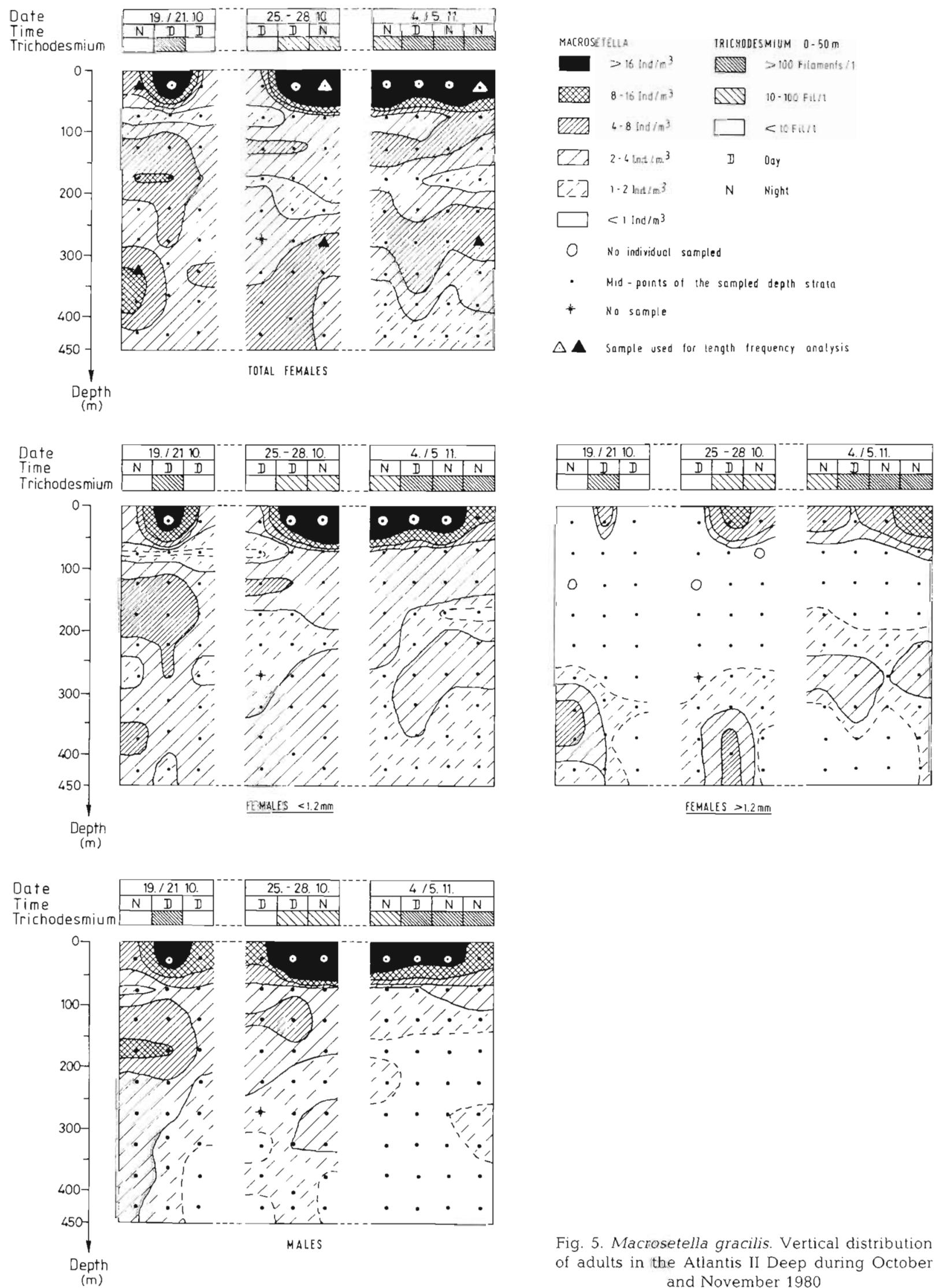

Fig. 5. Macrosetella gracilis. Vertical distribution of adults in the Atlantis II Deep during October and November 1980 
Table 3. Macrosetella gracilis. Temporal and regional variation in abundance beneath $1 \mathrm{~m}^{2}$ in the upper $450 \mathrm{~m}$. (a) Atlantis $\mathrm{II}$ Deep, February 1981; (b) Kebrit Deep, October 1980, (c) northern reference station, October 1980. $\bar{x}$ : Arithmetic mean; R: range; $n$ : number of sampling series

\begin{tabular}{|c|c|c|c|c|c|c|c|}
\hline \multirow{2}{*}{$\begin{array}{l}\text { Depth } \\
(\mathrm{m})\end{array}$} & \multirow[b]{2}{*}{$n$} & \multicolumn{2}{|c|}{ Females } & \multicolumn{2}{|c|}{ Males } & \multirow[t]{2}{*}{ Juveniles } & \multirow{2}{*}{$\begin{array}{c}\text { Ratio } \\
\text { females: males }\end{array}$} \\
\hline & & $\overline{\mathrm{x}}$ & $\mathrm{R}$ & $\overline{\mathrm{x}}$ & $R$ & & \\
\hline \multicolumn{8}{|c|}{ (a) Atlantis II, Feb 1981} \\
\hline $0-50$ & 6 & 70 & $(32-140)$ & 30 & $(12-44)$ & \multirow{3}{*}{$\begin{array}{c}- \\
(-)^{\mathrm{a}} \\
-\end{array}$} & $2: 1$ \\
\hline $50-450$ & 6 & 2100 & $(1700-2600)$ & 260 & $(180-360)$ & & $8: 1$ \\
\hline $0-450$ & 6 & 2200 & $(1700-2800)$ & 290 & $(190-390)$ & & $8: 1$ \\
\hline \multicolumn{8}{|c|}{ (b) Kebrit, Oct 1980} \\
\hline $0-50$ & 10 & 100 & $(44-140)$ & 130 & $(64-200)$ & - & $0.8: 1$ \\
\hline $50-450$ & 10 & 350 & $(260-400)$ & 64 & $(36-96)$ & $(-)^{d}$ & $5: 1$ \\
\hline $0-450$ & 10 & 450 & $(370-520)$ & 200 & $(140-260)$ & - & $2: 1$ \\
\hline \multicolumn{8}{|c|}{ (c) Northern, Oct 1980} \\
\hline $0-50$ & 1 & \multirow{2}{*}{\multicolumn{2}{|c|}{$\begin{array}{r}8 \\
340\end{array}$}} & \multirow{2}{*}{\multicolumn{2}{|c|}{$\begin{array}{r}40 \\
180\end{array}$}} & - & $0.2: 1$ \\
\hline $50-450$ & 1 & & & & & - & $2: 1$ \\
\hline $0-450$ & 1 & \multicolumn{2}{|c|}{350} & \multicolumn{2}{|c|}{220} & - & $1.6: 1$ \\
\hline \multicolumn{8}{|c|}{ a Solitary find } \\
\hline
\end{tabular}

3a). Comparing autumn 1980 and February 1981, the standing stock of females was at the same level, while the standing stock of males was one order of magnitude lower in winter 1981.

The vertical distribution of males was not very consistent, but showed a generally increased concentration with depth (Fig. 6). Values of $>1$ ind. $\mathrm{m}^{-3}$ were only found below $200 \mathrm{~m}$ and mostly between 300 and $400 \mathrm{~m}$. The sex ratio of females to males shifted with increasing depth in favour of the females, from a mean ratio of $2: 1$ in the upper $50 \mathrm{~m}$ to a mean of $10: 1$ below $300 \mathrm{~m}$.

Females showed a more distinct deep concentration maximum at 300 to $400 \mathrm{~m}$, which was consistent during day and night and for both size groups (Fig. 6). Larger females $(>1.2 \mathrm{~mm}$ ) congregated almost exclusively in the deep concentration maximum, whereas smaller females also showed some irregular concentrations above $300 \mathrm{~m}$. The size composition of the females correspondingly changed abruptly at $250 \mathrm{~m}$. In the pooled samples from the deeper layers of each profile, individuals $>1.2 \mathrm{~mm}$ accounted for 40 to $60 \%$ of total females, compared to only 4 to $9 \%$ above $250 \mathrm{~m}$. Eggbearing females were collected sporadically between the surface and $150 \mathrm{~m}$. Egg-bearing females in surface samples made up $3 \%$ on average, which is very low compared to the 10 times higher value observed in autumn

Northern Red Sea, October 1980

At the Kebrit Deep $\left(24^{\circ} \mathrm{N}\right)$ and the northern reference station ( $26^{\circ} \mathrm{N}$, Fig. 1), sampled in autumn 1980 , the populations of Macrosetella gracilis consisted almost exclusively of adults (Table $3 \mathrm{~b}, \mathrm{c}$ ). In the upper $450 \mathrm{~m}$, the range of variation in the total standing stock was much lower in the Kebrit Deep area than in the central Red Sea during the same season (Table 1). Females predominated, accounting for $>70 \%$ of adults. Total numbers of $M$. gracilis and the size composition of females from the single northern reference station were similar to those from the Kebrit Deep, but distribution patterns differed considerably.

In the Kebrit Deep area, males were concentrated mainly in the upper $50 \mathrm{~m}$ (Fig. 7), with a mean abundance of 2.6 ind. $\mathrm{m}^{-3}$. A small secondary maximum was found at 350 to $450 \mathrm{~m}$. Females showed the same general distribution pattern with 2 concentration maxima, of which the deep maximum was however much more pronounced (Fig. 7). Mean concentration in both peaks was 2 to 3 ind. $\mathrm{m}^{-3}$ and this pattern was consistent during both day and night. Large females $(>1.2 \mathrm{~mm})$ dominated. They congregated preponderantly at greater depths, whereas the majority of the smaller females were concentrated in the upper $50 \mathrm{~m}$ (Fig. 7). Egg-bearing females were regularly found in the upper $50 \mathrm{~m}$ and occasionally egg-bearing individuals descended as deep as $150 \mathrm{~m}$. At the surface about $16 \%$ of females carried eggs. A size-related difference was not apparent in this case. The sex ratio of females to males averaged $0.8: 1$ in the surface zone and increased to $7: 1$ at 350 to $450 \mathrm{~m}$.

The vertical distribution pattern of Macrosetella gracilis observed at the northern reference station differed from that near the Kebrit Deep in 2 main features (Table 3c): (1) males congregated at greater depths 


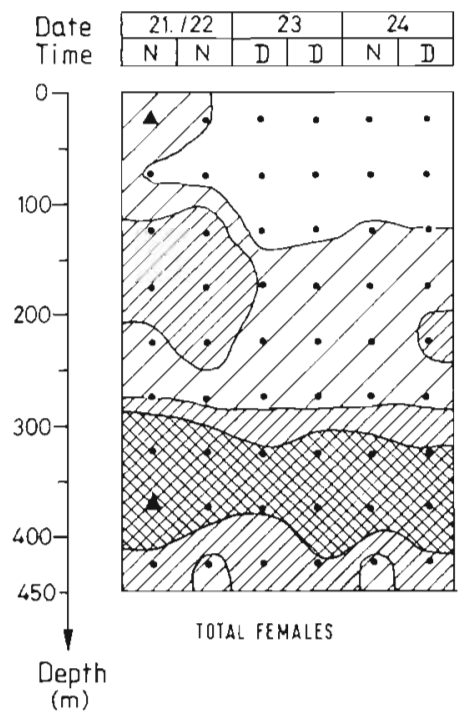

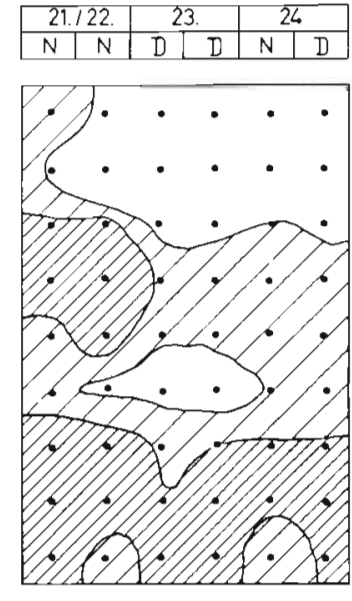

FEMALES $<12 \mathrm{~mm}$
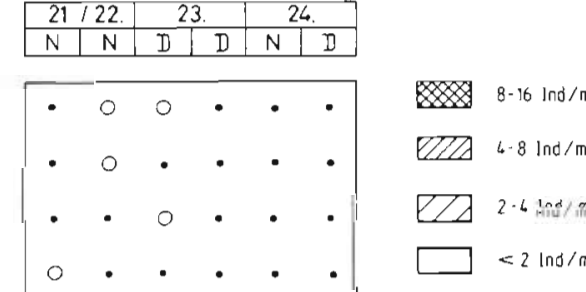

- Mid-points of the sampled depth strata

No individual

somplea

A Sample used for length trequency analysis

D Day

$N$ Nigh:

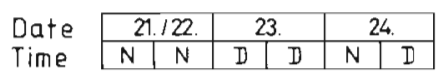

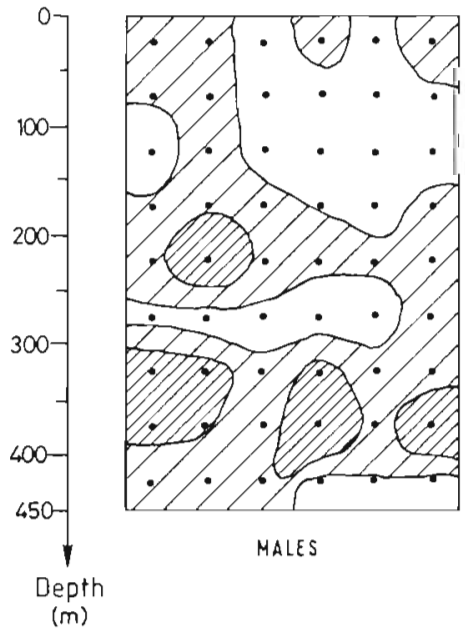

below $300 \mathrm{~m}$; (2) there was also no surface maximum for females; they were concentrated at 350 to $450 \mathrm{~m}$ ( 2.5 ind $\mathrm{m}^{-3}$ ) and were mainly large $(>1.2 \mathrm{~mm})$. Females with egg sacs were found irregularly between 50 to $300 \mathrm{~m}$. The sex ratio of females to males shifted from $0.2: 1$ in the upper $50 \mathrm{~m}$ to $2: 1$ at 350 to $450 \mathrm{~m}$

\section{Oil droplets in female Macrosetella gracilis}

The quantity of oil droplets in female Macrosetella gracilis was regularly considered during the present analysis as an obvious special feature that might be related to the condition of the stock. Results from all stations and for different Trichodesmium situations are summarized in Fig. 8. Generally, more oil droplets were found in individuals from deeper water layers than in those from the surface zone. However, individuals taken at the surface during highest concentrations of Trichodesmium (Atlantis II Deep, Fig. 8C), also contained many oil droplets.

\section{DISCUSSION}

\section{Population structure and life cycle of Macrosetella gracilis in the Red Sea}

When resolving the vertical structure of a plankton population by the use of closing net samples, the possibility of contamination of deep samples by surface organisms has to be considered. For the sampling 

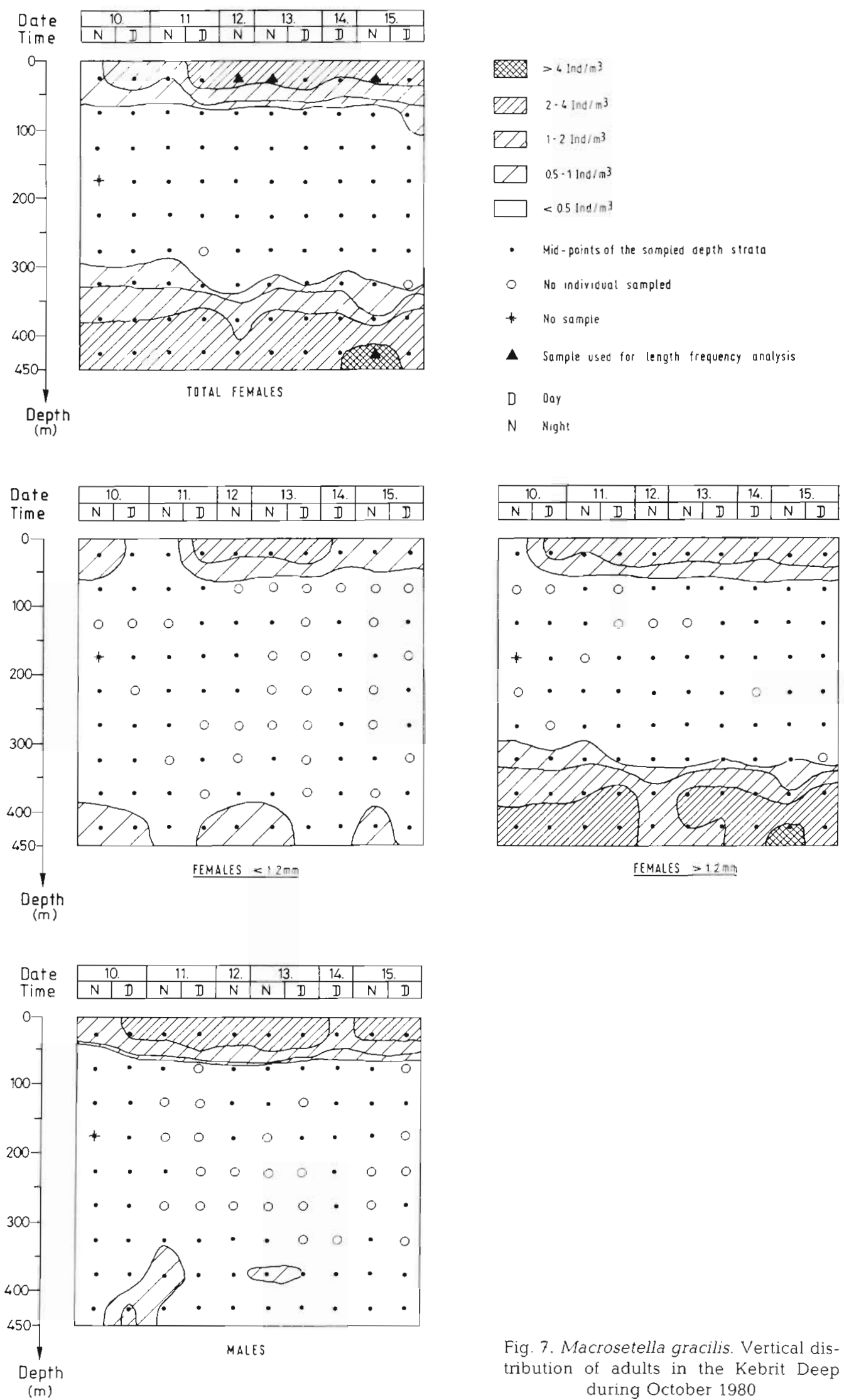

Fig. 7. Macrosetella gracilis. Vertical distribution of adults in the Kebrit Deep during October 1980 


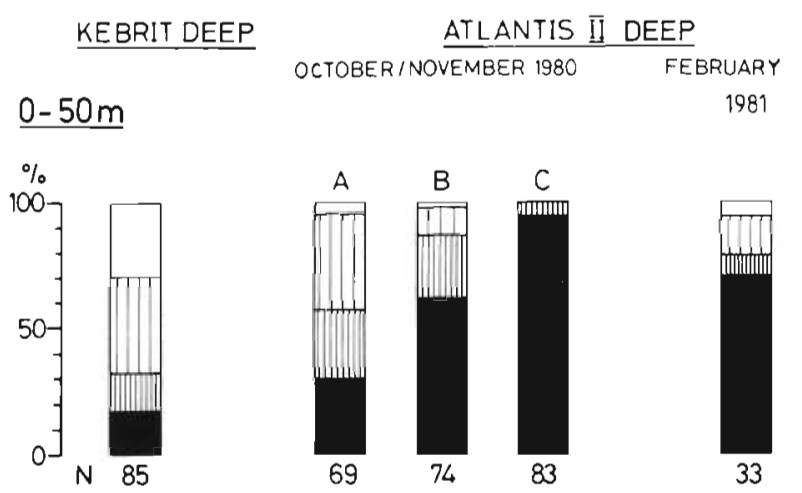

\section{$\underline{250-450 m}$}
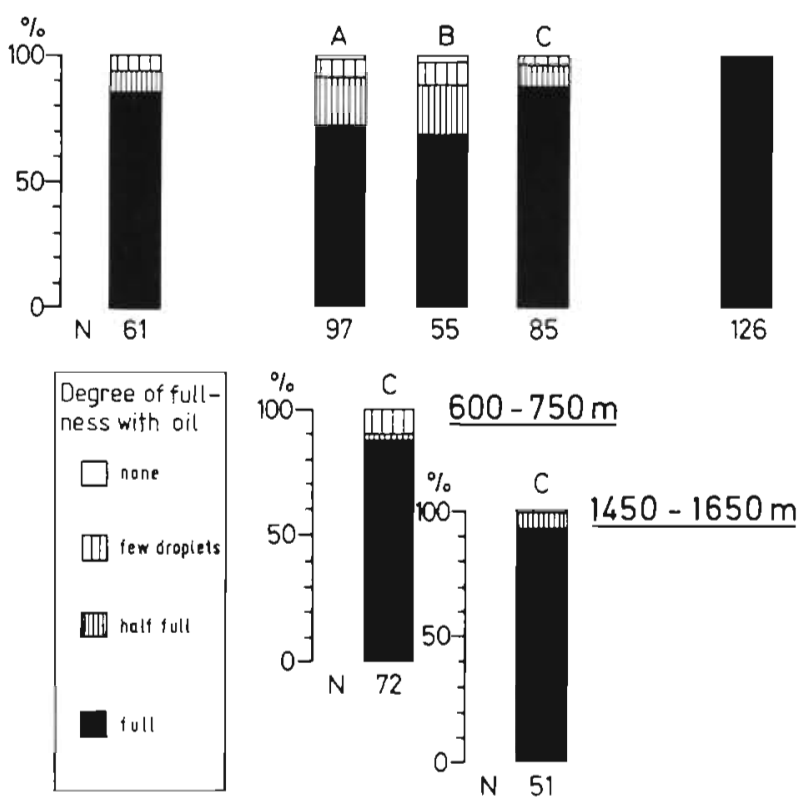

Fig. 8. Macrosetella gracilis. Degree of tullness with oil droplets observed in females from various water depths. $N$ : number of individuals examined. A, B, C: various densities of Trichodesmium filaments in the upper $50 \mathrm{~m} ; \mathrm{A}=4$ filaments $\mathrm{l}^{-1}, \mathrm{~B}=70$ filaments $\mathrm{l}^{-1}, \mathrm{C}=650$ filaments $\mathrm{l}^{-1}$

device used in the present study, Weikert \& John (1981) presented some quantitative assessment on this problem and indicated small contamination effects only, using a larger mesh size of $0.3 \mathrm{~mm}$. Reducing the mesh size, and thus the sizes of organisms considered, might in principle increase the contamination problem. However, in the present study, distinct differences were observed between surface and deep water populations. Contamination obviously had no severe effect on the sampling results, however for organisms caught sporadically and in low numbers only, depth allocation remains uncertain.
In general, the population structure of Macrosetella gracilis during autumn and winter differs substantially within the Red Sea. Trichodesmium appears to be the key factor governing the ontogenetic composition, the size distribution of adults, the sex ratio, and the percentage of reproductive females. The details presented under 'Results' are schematically summarized in Fig. 9, which serves as a basis for some generalization and discussion of principle features of the population biology of this species in the Red Sea. In the following, the paragraph numbering corresponds to the numbering of populations of $M$. gracilis in Fig. 9.

(1) Reproduction of Macrosetella gracilis populations is restricted to sea surface layers and depends on Trichodesmium bloom conditions. Only within these blooms do the pseudopelagic nauplii and copepodids find the substrate of filaments they need for their development. The abundance of the copepod within the bloom is correspondingly high. Female and male copepods are present in almost equal numbers, and a large proportion of the females carry egg sacs. On average small females $(<1.2 \mathrm{~mm})$ are more numerous and have a higher percentage of egg-bearers than larger females.

(2) In the water column beneath a Trichodesmium bloom, the population consists mainly of adults. The sporadic occurrence of juveniles remains uncertain, as some of these small individuals may also have entered the closed sampling nets during hauling through the densely populated patches of Trichodesmium. Males are less abundant than females at this depth. The difference in sex ratio between surface and deeper layers may indicate a lower survival rate of males at greater depths. Alternatively, a greater downward flux of females seems possible. Also within the group of females, larger specimens (>1.2 $\mathrm{mm}$ ) seem to move down more rapidly or survive longer at greater depths than smaller ones, as their proportion increases with depth. The passive sinking velocity of copepods has been found to vary between 36 and $720 \mathrm{~m} \mathrm{~d}^{-1}$ (Parsons et al. 1977). Thus, it seems possible that these copepods sink to a few hundred meters within a very short time. The possible retarding effect of the long, thin body form of Macrosetella gracilis on its sinking velocity has not been investigated, however.

(3) Without a Trichodesmium bloom, as in February 1981, no surface population of Macrosetella gracilis develops. Females $>1.2 \mathrm{~mm}$ congregate in the upper part of the oxygen minimum at a depth of 300 to $400 \mathrm{~m}$. The abundance of smaller females also increases with depth, but shows no strong tendency to congregate at a certain depth. Males are rare in this winter situation and juveniles are no longer present. A small percentage of females is still carrying egg-sacs in the nearsurface water down to $150 \mathrm{~m}$, but juveniles cannot 
develop successfully, because sufficient amounts of Trichodesmium are lacking. It can be presumed that the autumn population of $M$. gracilis is still present in the following winter. After reproduction in Trichodesmium-rich surface waters, the adults congregate at greater depth just above the oxygen minimum zone. The ecological significance of this behaviour will be discussed in the next section.

Regional differences observed in the vertical distribution pattern of Macrosetella gracilis can be summarized and interpreted as follows (cf. Fig. 9):

(4) Regarding the midwater population present at depths of more than $300 \mathrm{~m}$, the autumn situation in the northern Red Sea (Kebrit Deep) looks similar to the winter situation in the central Red Sea, when no Trichodesmium bloom was noticed. It is a small population, characterized by a low proportion of males and a lack of juvenile stages. The dominance of large females, however, is much more pronounced in the Kebrit Deep. The aggregation of large females is found ca $100 \mathrm{~m}$ deeper than in the central area, which corresponds to the regional differences in the depth of the oxygen minimum zone (Fig. 2). Thus, it may be assumed that the decreasing oxygen concentrations act as a stimulus that prevents larger females from descending further.
(5) In Kebrit Deep, the surface population of Macrosetella gracilis is completely separated from the population at midwater depths. It resembles Population (1) found in the central Red Sea during the Trichodesmium bloom with respect to sex ratio and size composition of females. However, this northern population is less numerous than Population (1) and has a lower mean percentage of egg-bearing females. Juvenile stages are not present, and Trichodesmium is scarce. This surface population of $M$. gracilis may be part of an expanding Population actively reproducing within a Trichidesmium bloom nearby. Such a bloom may well be missed during a survey because of the very patchy distribution of Trichodesmium. Alternatively, the observed Population (5) may be interpreted as part of an old surface population after bloom conditions have disappeared. It may have been separated from the related deep population by drift processes.

(6) North of the Kebrit Deep, at $26^{\circ} \mathrm{N}$, only one deep Macrosetella gracilis population was found, which resembled Population (4) of the Kebrit Deep with respect to abundance and size composition of the females. However, the large proportion of males seemed to be atypical for a midwater population of this species, according to the population structure observed farther to the south. The limited data compiled from a single
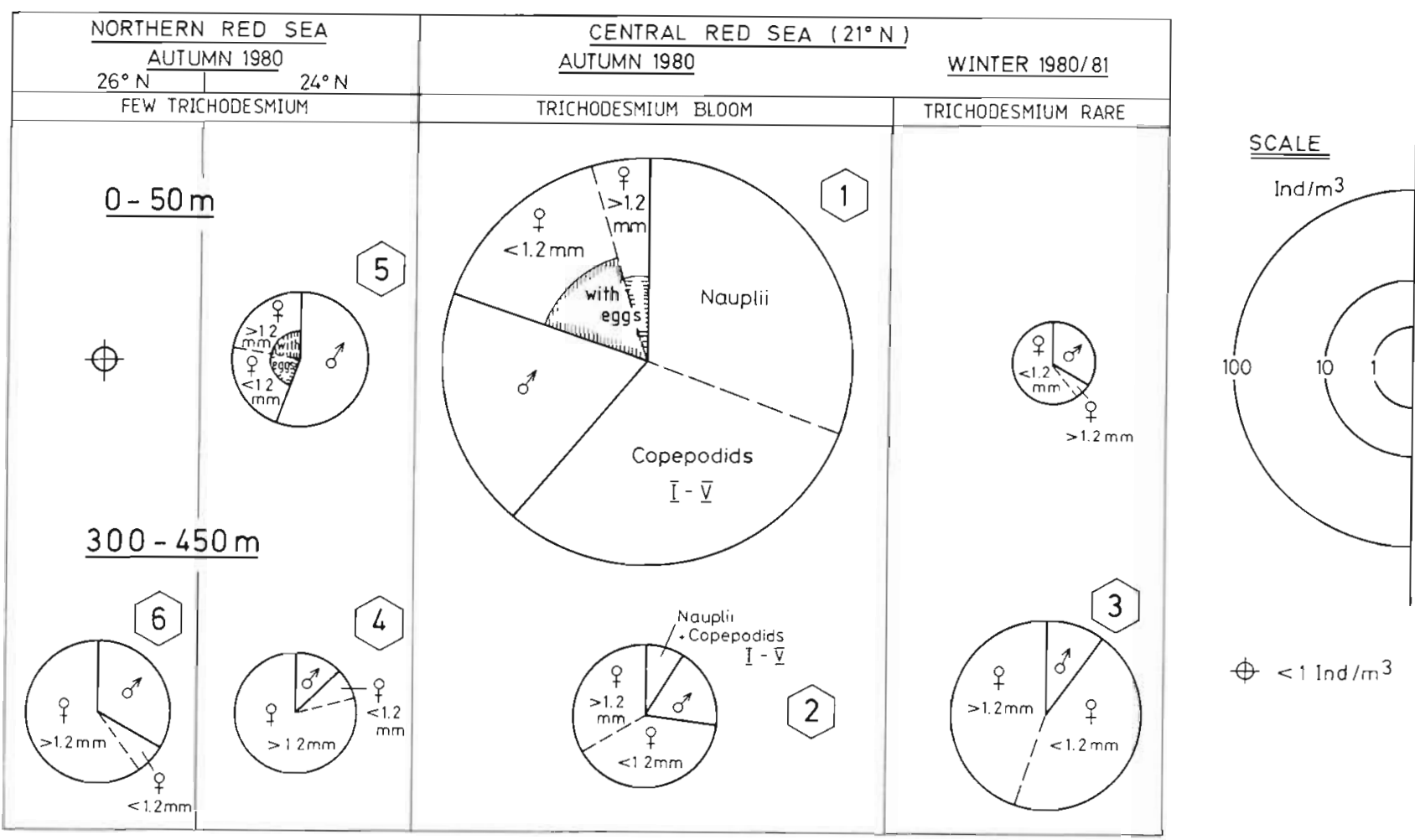

Fig. 9. Macrosetella gracilis. Schematic depiction of population structure in the central and northern Red Sea during autumn and winter, 1980-81 Numbers (1) to (6) refer to explanations given in the text 
vertical series are insufficient for a reasonable interpretation of this regional difference in the population structure.

The results so far obtained on the population structure and vertical distribution of Macrosetella gracilis in the Red Sea above a depth of $450 \mathrm{~m}$ allow the following general conclusions

- Reproduction of the copepod takes place only in the epipelagic zone in areas with large amounts of Trichodesmium spp.

- Midwater populations consist of adult Macrosetella gracilis only. After development in the surface zone during favourable conditions, they congregate in the mesopelagic zone in the upper part of the oxygen minimum layer. Diurnal vertical movements are not apparent.

- The midwater populations are dominated mainly by large females (>1.2 $\mathrm{mm}$ ) and continue to exist after conditions for reproduction are no longer favourable.

\section{Ecological significance of midwater and deep sea populations of Macrosetella gracilis}

The conspicuous depth distribution of Macrosetella gracilis raises questions concerning the function of the deep-dwelling part of the population within the life cycle of the copepod. Two explanations are presented here.

Firstly it is suggested that the midwater population represents a resting stock surviving at this depth until favourable Trichodesmium conditions develop again at the surface. Such resting stocks are known from a variety of calanoid copepod species, which are undergoing a 'diapause' (Alldredge et al. 1984). In the Red Sea, a deep population of Rhincalanus nasutus, dwelling in the oxygen minimum zone at 450 to $600 \mathrm{~m}$, is also considered to be such a resting stock (Weikert 1980, 1982, Beckmann 1984), For marine harpacticoid copepod species, similar phenomena have not previously been reported. One reason for this may be that the relatively few pelagic harpacticoid species are too scarce to be sampled in sufficient numbers by traditional methods to allow a detailed investigation of their depth distribution (Boxshall 1979). Moreover, species such as Macrosetella gracilis and Microsetella spp. have not been sampled quantitatively by the commonly used $0.3 \mathrm{~mm}$ mesh nets. This was demonstrated by simultaneous sampling using $0.3 \mathrm{~m}$ and 0.1 $\mathrm{mm}$ mesh nets during the Meseda 3 cruise in the Red Sea. No juveniles and only one tenth of the adult $M$. gracilis were retained by the coarser mesh size (Böttger 1985).

The high number of oil droplets observed in the deep-living females indicate considerable lipid stor- age, typical for resting stages of calanoid copepods (Conover 1962, Hirche 1983, Alldredge et al. 1984). A biochemical analysis of the Macrosetella gracilis specimens for physiological determinations such as protein, lipid or enzyme content is not practicable after fixation in formaldehyde. In particular, the lipid content of copepods can be greatly reduced by formaldehyde fixation (Morris 1972). The determination of metabolism, including respiration, excretion and mobility, is also possible only with living specimens. Therefore, the presence of resting stages of $M$. gracilis can only be inferred. If $M$. gracilis has an ontogenetic migration cycle only one phase of it, the downward migration, was observed during the present study. It remains to be determined whether an upward migration occurs during other periods or in other parts of the Red Sea.

Secondly, the possibility has to be considered that the deep population of Macrosetella gracilis is moribund. The relative percentage of carcasses among the deep population, however, was not significantly higher than that among the surface population. Furthermore, compared to the percentage of carcasses of other copepod species, that for $M$. gracilis was rather low. In view of the different distribution pattern observed for the 2 size groups of females, it may also be possible that only the population of large females $(>1.2 \mathrm{~mm}$ ) represents a resting stock, while the smaller females are produced in surface waters for rapid reproduction and do not survive non-bloom periods.

Generally, the occurrence of Macrosetella gracilis in deep waters is of special importance for the nutrient cycle in the area studied. Nitrogen fixed by Trichodesmium spp. at the sea surface is transported into deep water by the copepod and becomes available for other planktonic organisms there after excretion or through the food web. The relative importance of $M$. gracilis within total copepods, which are the most numerous metazoan group in $0.1 \mathrm{~mm}$ mesh nets, was far greater in the deep sea $(40 \%)$ than at the surface ( $2 \%$ ) (Böttger 1987). It is still too early to estimate nitrogen input to the deep sea via $M$. gracilis, as important numerical data on this copepod at depths below $500 \mathrm{~m}$ are restricted to a few sampling series in the Red Sea. In evaluating the ecological significance of Trichodesmium spp. blooms in tropical pelagic areas, however, these processes will have to be taken into account.

\section{Comparison with other pelagic areas}

The abundance data for adult Macrosetella gracilis in the Red Sea can be compared with those from other fine mesh net sampling programs ( $\leqslant 0.1 \mathrm{~mm}$ mesh size) in the southern Atlantic Ocean (Calef \& Grice 1966), 
the Caribbean Sea (Roman 1978) and the Sargasso Sea (own unpubl. data). Usually, between zero and over 100 ind per $\mathrm{m}^{2}$ of the sea surface were counted in the upper $200 \mathrm{~m}$. Extreme values of $6000 \mathrm{ind} . \mathrm{m}^{-2}$ were recorded within Trichodesmium blooms (Calef \& Grice 1966). Abundance values observed in the present study for the upper $200 \mathrm{~m}$ of the Red Sea varied from 120 to 8300 ind. $\mathrm{m}^{-2}$. They are thus comparable to the more extreme values found in the Atlantic. Published information on the abundance of $M$. gracilis nauplii and copepodids is scarce. From data reported by Tokioka \& Bieri (1966), a mean abundance of 1.4 nauplii $\mathrm{m}^{-2} \mathrm{can}$ be calculated for the upper $10 \mathrm{~cm}$ of the water column. For the Red Sea, much higher values have been obtained. Even when assuming an equal distribution over the upper $20 \mathrm{~m}$, the average abundance of nauplii in the upper $10 \mathrm{~cm}$ would amount to $25 \mathrm{ind} . \mathrm{m}^{-2}$. This is certainly an underestimation, because the concentrations at the surface will be higher than the average value for the upper $20 \mathrm{~m}$.

Since the in vitro experiments of Björnberg (1965), it is known that blooms of Trichodesmium act as potential 'Kindergarten' for juvenile Macrosetella gracilis. In view of the tremendous amount of literature dealing with the mass development of these algae in tropical pelagic areas (reviewed by Carpenter 1983), the lack of any reference to the occurrence of these juvenile copepods is surprising. This omission is presumably due to the sampling methods used and not to a scarcity of the copepod. Zooplankton samples taken within Trichodesmium blooms have in most cases been obtained with $0.3 \mathrm{~mm}$ mesh nets, which do not even catch adult $M$. gracilis quantitatively (see above). The larger zooplankton organisms associated with Trichodesmium blooms were investigated in a long-term study along the Indian Coast (Nair et al. 1980). Unfortunately, all Trichodesmium filament bundles and thus any $M$. gracilis nauplii that may have been attached to them were carefully removed prior to the analysis of the zooplankton samples.

Midwater and deep populations of Macrosetella gracilis comparable to that found in the Red Sea during the present study have not yet been reported from other pelagic regions. All published information on finds of $M$. gracilis in water layers below $200 \mathrm{~m}$ /Grice 1963, Owre \& Foyo 1964, Deevey \& Brooks 1977, Boxshall 1979, Weikert 1982) are based on samples taken in $0.2 \mathrm{~m}$ or $0.3 \mathrm{~mm}$ mesh nets, which cannot catch that species quantitatively. In most cases single specimens, mainly adults, were found. Some authors assume that deep samples have been contaminated by surface organisms (Boxshall 1979). In view of the inadequate sampling methods, however, these scattered finds may also indicate that this species inhabits deep waters in other pelagic regions as well.
Acknowledgements. We thank Dr H. Weikert, who organized the plankton programme in the Red Sea and supported the study. The constructive comments of an anonymous referee are gratefully acknowledged. Dr C. Heckman improved the English text. The Saudi-Sudanese Red Sea Joint Commission, Jeddah, and the Bundesministerium für Forschung und Technologie, Federal Republic of Germany, funded the Meseda 3 cruise. This study was supported by Deutsche Forschungsgemeinschaft grant Schn 207/7-1 to D. Schnack.

\section{LITERATURE CITED}

Alldredge, A. L., Robison, B. H., Fleminger, A., Torres, J. J., King, J. M. Hamner, W. M. (1984). Direct sampling and in situ observation of a persistent copepod aggregation in the mesopelagic zone of the Santa Barbara Basin. Mar. Biol. 80: 75-82

Beckmann, W (1984). Mesozooplankton distribution on a transect from the Gulf of Aden to the central Red Sea during the winter monsoon. Oceanologica Acta 7: 87-102

Belogorskaya, E. V (1970). Qualitative and quantitative distribution of phytoplankton in the Red Sea and Gulf of Aden in October/November 1963. Biol. Morja (Kiev) 21: 133-152 (Russian)

Bjömberg, T K. S. (1965). Observations on the development and the biology of the Miracidae Dana (Copepoda: Crustacea). Bull. mar. Sci. 15: 512-520

Borstad, G. A. Borstad, L. E. (1977). The Oscillatoria erythraea (Cyanophyta) community of associates. In: Stewart, H. B. $\mathrm{Jr}$ (ed.) Cooperative investigations of the Caribbean and adjacent regions - II. FAO Fish. Rep. 200: 51-57

Böttger, R. (1985). Untersuchungen zur Verteilung der kleinen Metazoa im Plankton des Roten Meeres, unter besonderer Berücksichtigung cyclopoider und harpacticoider Copepoden. Dissertation, University of Hamburg

Bottger, R. (1987). The vertical distribution of micro- and small mesozooplankton in the central Red Sea. Biol. Oceanogr. 4: 383-402

Böttger-Schnack, R. (1989). Body length of temale Macrosetella gracilis (Copepoda: Harpacticoida) from various depth zones in the Red Sea. Mar. Ecol. Prog. Ser. 52: 33-37

Boxshall, G. A. (1979). The planktonic copepods of the northeastern Atlantic Ocean: Harpacticoida, Siphonostomatoida and Mormonilloida. Bull. Br. Mus, nat. Hist. (Zool.) 35: $201-264$

Bryceson, J. (1980). Nitrogen fixation and the autecology of Oscillatoria erythraea (Ehrenberg) Kuetzing, a planktonic cyanophyte from the coastal waters of Tanzania: a preliminary investigation. In: Proc of the Symposium on the coastal and marine environment of the Red Sea, Gulf of Aden and tropical western Indian Ocean', Vol. III. Khartoum, January 9-14, 1980. The Red Sea \& Gulf of Aden Environmental Programme, Jeddah, p. 471-488

Calef, G. W. Grice, G, D. (1966). Relationship between the bluegreen alga Trichodesmium thiebautii and the copepod Macrosetella gracilis in the plankton off northeastern South America. Ecology 47.855-856

Carpenter, E. J. (1983). Physiology and ecology of marine planktonic Oscillatoria (Trichodesmium). Review. Mar. Biol. Lett. 4: 69-85

Conover, R. J. (1962). Metabolism and growth in Calanus hyperboreus in relation to its life cycle. J. Cons. perm. int. Explor. Mer. 153: 190-197

Corredor, J. E. (1977). Aspects of phytoplankton dynamics in 
the Caribbean Sea and adjacent regions. In: Stewart, H. B. $\mathrm{Jr}$ (ed.) Cooperative investigations of the Caribbean and adjacent regions - II. FAO Fish. Rep. 200: 101-114

Deevey, G. B., Brooks, A. L. (1977). Copepods of the Sargasso Sea off Bermuda: species composition, and vertical and seasonal distribution between the surface and $2000 \mathrm{~m}$ Bull. mar Sci. 27: 256-291

Devassy, V P., Bhattathiri, P. M. A., Qasim, S. Z. (1978). Trichodesmium phenomenon. Indian J. mar Sci. 7 168-186

Goering, J. J., Dugdale, R. C., Menzel, D. W. (1966). Estimates of in situ rates of nitrogen uptake by Trichodesmium sp. in the tropical Atlantic Ocean. Limnol. Oceanogr 11: $614-620$

Grice, G. D. (1963). Deep water copepods from the western North Atlantic with notes on five species. Bull. mar. Sci. 13: 493-501

Hirche, H.-J. (1983). Overwintering of Calanus finmarchicus and Calanus helgolandicus. Mar. Ecol. Prog. Ser. 11 $281-290$

Krishnaswamy, S. (1951). Development of a harpacticoid copepod Macrosetella gracilis (Dana). Madras Univ. J. 21(B): 2

Lange, J., Falk, E., Zeitner, R. (1981). Meseda 3-Data hydrography: water chemistry. Tech. Rep. No. 34G, Preussag Marine Technology Dept, Hannover: 1-145

Michel, H. B., Foyo, M. (1977). Studies of Caribbean zooplankton. In: Stewart, H. B. Jr (ed.) Cooperative investigations of the Caribbean and adjacent regions - II. FAO Fish. Rep. 200: 275-289

Moore, H. B., Foyo, M. (1963). A study of the temperature factor in twelve species of oceanic copepods. Bull. mar. Sci. 13: $502-515$

Morcos, S. A. (1970). Physical and chemical oceanography of the Red Sea. Oceanogr. mar. biol. A Rev. 8: 73-202

Morris, R. J. (1972). The preservation of some oceanic animals for lipid analysis. J. Fish. Res. Bd Can. 29: 1303-1307

Nair, V. R., Devassy, V. P., Qasim, S. Z. (1980). Zooplankton and Trichodesmium phenomenon. Indian J. mar. Sci. 9: 1-6

This article was submitted to the editor
Naqvi, S. W A., Hansen, H. P., Kureishy, T. W. (1986). Nutrient uptake and regeneration ratios in the Red Sea with reference to nutrient budgets. Oceanologica Acta 9: $271-276$

Owre, H. B., Foyo, M. (1964). Report on a collection of Copepoda from the Caribbean Sea. Bull. mar Sci. 14: 359-372

Parsons, T R., Takahashi, M., Hargrave, B. (1977). Biological oceanographic processes, 2nd edn. Pergamon Press, Oxford

Roehr, M. G., Moore, H. B. (1965). The vertical distribution of some common copepods in the Straits of Florida. Bull mar. Sci. 15: 565-570

Roman, M. R. (1978). Ingestion of the blue-green algae Trichodesmium by the harpacticoid copepod, Macrosetella gracilis. Limnol. Oceanogr. 23: 1245-1255

Steedman, H. F. (1976). Examination, sorting and observation fluids. In: Steedman, H. F. (ed.) Zooplankton fixation and preservation. Monogr. on oceanogr. methodol. 4. Unesco Press, Paris, p. 182-183

Thiel, H., Weikert, H. Karbe, L. (1986). Risk assessment for mining metalliferous muds in the deep Red Sea. Ambio 15: $34-41$

Tokioka, T., Bieri, R. (1966). Juveniles of Macrosetella gracilis (Dana) from clumps of Trichodesmium in the vicinity of Seto. Publ. Seto Mar. Biol. Lab. 14: 275-282

Weikert, H. (1980). On the plankton of the central Red Sea. A first synopsis of results obtained from the cruises Meseda I and Meseda II. In: Proc of 'Symposium on the coastal and marine environment of the Red Sea, Gulf of Aden and tropical western Indian Ocean', Vol. III. Khartoum, January 9-14, 1980. The Red Sea \& Gulf of Aden Environmental Programme, Jeddah, p. 135-167

Weikert, H. (1982). The vertical distribution of zooplankton in relation to habitat zones in the area of the Atlantis II Deep, central Red Sea. Mar. Ecol. Prog. Ser. 8: 129-143

Weikert, H., John, H.-C. (1981). Experiences with a modified Bé multiple opening-closing plankton net. J. Plankton Res. 3: $167-176$

Manuscript received: December 15, 1987

Revised version accepted: November 21, 1988 